\title{
DUNALIELLA ЗАМГИЙН ФИЗИОЛОГИ, БИОХИМИЙН СУДАЛГААНЫ ДУН
}

Б.Одгэрэл, Д.Цэрэндулам

Ерөнхий болон сорильн биологийн хүрээлэнгийн Микробын Нийлэгжлийн Лаборатори, Шинжлэх ухааны Академи, Монгол улс Цахимиуудан: odgerel@biology.mas.ac.mn,odgoo22@gmail.com

\begin{abstract}
Хураангуй
Dunaliella нь байгалийн эрс тэрс орчинд дасан зохицож ургах чадвартай нэгэн төрлийн бичил замаг бөгөөд уураг, өөх тос, бета каротин зэрэг биологийн идэвхт нэгдлээр баялаг тул биотехнологийн үйлдвэрлэлд өргөнөөр ашигладаг. Dunaliella замгийн морфологи, физиологи, биохимийн судалгааг хийснээр ичаашид практикт ашиглах боломжтой шинж чанарыг тогтоох чухал ач холбогдолтой. Микробын нийлэгжлийн лабораторийн бичил биетний сан дахь Dunaliella Д-1, Д-6, Д-7 өсгөврийн эсийн хэлбэр зүйн шинж (эсийн хэлбэр, хэмээээ, хроматофорын хэлбэр), өсөлтийн эрчим, биомасст дахь уургийн агууламжийг сонгомол орчинд өсгөвөрлөж тодорхойлов. Эдгээр өсгөврийн өсөлтийн эрчим 3 дахь хоногоос эрчимжсж, 6-7 дахь өдрөө ургалтын дээд түвииндээ хүрч байв. Dunaliella Д-1, Д-6 өсгөврийн өсөлтийн эрчим ойролиоо байсан ба эсийн тоогоор авч үзэхэд Д-7 өсгөвөр нь Д-1, Д-6 өсгөвруҮдээс 2 - 2.9 дахин их эс хуримтлуулж байсан. Dunaliella Д-1 нь $62.2 \%$ уураг агуулэс (Dunaliella Д-6 ба Д-7 өсгөвөр нь 36.1\% ба 38.15\%) бусад өсгөврөөс илҮҮ тул иаашдын судалгаанд сонгосон.
\end{abstract}

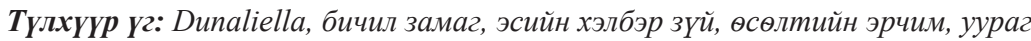

\section{ОРШИЛ}

Замаг нь гол төлөв далай тэнгис, нуур цөөрөм, гол мөрний усанд болон чийгтэй хөрс, мод, чулууны гадаргууд ургадаг бөгөөд нэг эст өчүүхэн биетнээс хэдэн арван метр хүртэл хэмжээтэй байдаг. Замгийг бүтэц зохион байгуулалтаар нь макро ба микро замаг гэж ангилдаг. Микро буюу бичил замаг нь экологийн янз бүрийн нөхцөлд дасан зохицож, хөрс, ургамал, амьтан, шавжтай симбиоз харилцан үйлчлэлд оршиж, хөрсний үржил шимийг сайжруулах, ургамлыг шим тэжээлээр хангах, газрын баялаг бүрдүүлэх, бодисын эргэлтэд оролцох, агаарыг цэвэршүүлэх зэрэг чухал үүрэгтэйгээс гадна үйлдвэрлэлийн микробиологид уураг, витамин, аминхүчил, антибиотик, ферментийн гол нийлэгжүүлэгч болгон ашигладаг [1].

Дэлхийн олон оронд бичил замгийн олон төрөл зүйлийг янз бүрийн зорилгоор ашиглаж байна. Учир нь бичил замгийг дээд ургамалтай харьцуулахад богино хугацаанд их хэмжээний бүтээгдэхүүн үйлдвэрлэх чадвартай, фотосинтезийн эрчимжилт болон тэжээллэг чанараараа илүү өндөр байдаг. Тухайлбал: Chlorella, Dunaliella, Spirulina зэрэг төрлийг бичил замгийн судлаачид ихээхэн сонирхох болсон ба эдгээр замгийг ашиглан хүнс тэжээлийн 
нэмэлт, хүнс ба гоо сайхны бүтээгдэхүүн, глицерин, биотүлш зэрэг эрүүл мэнд, экологийн өндөр ашигтай бүтээгдэхүүнийг ихээр үйлдвэрлэх болсон $[2,3,4]$.

Ногоон замгийн нэгэн төлөөлөгч болох дунальелла замаг нь давслаг орчинд ургадаг хөдөлгөөнт нэг эст замаг [5]. Эсийн хэмжээ нь 4-10 мкм өргөн, 6-15 мкм урттай, ихэнхдээ дугуй зуйван хэлбэртэй. Уртаараа тэнцүүхэн хос шилбүүртэй, аяга хэлбэрийн ганц том хлоропласттай. Хлоропласт нь полисахаридын мөхлөгөөр хүрээлэгдсэн том периноидыг агуулна. Бусад замгаас ялгарах гол онцлог нь хатуу полисахарид бүхий эсийн хана байхгүй $[6,7]$. Тэдгээрээс D.salina, D.dazva зэрэг зүйлүүд ургах орчиноосоо хамааран өнгөө улбар шар, шар, хүрэн улаан болгон хувиргадаг. Dunaliella -ийн төрлөөс хамгийн өргөн судлагдаж, практикт ашиглагдаж байгаа нь D.salina, D.viridis, D.minutica зэрэг зүйл байдаг [8].

Дунальелла замгийн анхны бичиглэлийг Парисийн Академич Пайну 1836 онд хийжээ. Дараа нь 1905 онд Теодерско, Ягода 1928, 1932 нар дээрх замгийн талаар судалгаа явуулж бие даасан төрөл болохыг баталсан байна. Энэ замгийн каротины бионийлэгжилтийн судалгааны обьектоор D.salina зүйлийг голчлон сонгосон байдаг. Дунальелла замаг нь натри хлорын өндөр концентрацитай тэжээлт орчинд эсийн дотоод хэсэгт глицерол ялгаруулж, зохицон амьдрах чадвартай юм. Мөн эрдэс давснаас гадна мочевин, спиртийн шаар, пептон зэрэг органик бодис ашиглан гэрэлтэйд үрждэг онцлогтой [9].

Манайд энэ замгийн судалгааг анх 1972 онд Л.Пүрэв, Дорнод аймгийн Сангийн далай нуураaс D.viridis зүйлийг тодорхойлсон байдаг ба уг зүйлийг ховор ургамлын тоонд оруулсан байдаг. Сүүлийн жилүүдэд судлаачид ногоон замгийн Dunaliella төрлийг нилээд сонирхож байна. Учир нь дунальелла төрлийн замгууд хүнсний бета-каротинаар баялаг төдийгүй бусад байгалийн каротинойдын холимогийг агуулж байдаг[10]. Иймд Монгол орны давстай нууруудаас ялгасан дунальелла бичил замгийн өсөлтийн эрчим болон тэдгээрийн биомасст агуулагдах уургийн агууламжийг тогтоох нь энэ судалгааны ажлын гол зорилго болно.

\section{СУДАЛГААНЫ МАТЕРИАЛ БА АРГА ЗУЙ}

\section{Судалгааны материал}

Судалгаанд Ерөнхий болон Сорилын Биологийн хүрээлэнгийн Микробын нийлэгжлийн лабораторийн бичил биетний санд хадаглагдаж байдаг, Монгол орны давстай нуураас ялгасан Dunaliella Д-1, Д-6, Д-7 өсгөврийг ашигласан.

Арга зүй: Өсгөврийг Ван-ниля, Масюк орчингууд ургуулсан ба ургалтын ижил түвшинтэй суспензээс шингэн тэжээлд тарьж $24-27^{\circ} \mathrm{C}$ температуртай, 8-10 клк гэрэлтүүлэлтэнд, $\quad 0.05 \%$ нүүрс хүчлийн хийн агааржуулалттай орчинд 8 хоног өсгөвөрлөн биомассыг цуглуулсан. Өсөлтийн эрчимийг Горяевын торыг ашиглан эсийн тоогоор гаргасан. Мөн дунальелла замгийн хуурай биомасс дахь уургийн агууламжийг микрокъелдалийн аргаар тодорхойлов [11].

\section{СУДАЛГААНЫ УР ДУН БА ХЭЛЭЛЦУУЛЭГ}

\section{1. Замгийн өсөлтийн эрчим}

Dunaliella Д-1 өсгөврийг Ван-ниля тэжээлт орчинд, харин Dunaliella Д-6, Д-7 өсгөвөрүүдийг Масюк тэжээлт орчинд 24$27^{\circ} \mathrm{C}$ хэмтэй, 8-10 клк гэрэлтүүлэлтэнд,
$0.05 \%$ нүүрс хүчлийн хийн агааржуулалттай орчинд 8 хоногийн турш өсгөвөрлөсөн ба эсийн тоог өдөр бүр Горяевын торыг ашиглан тоолж, өсөлтийн эрчимыг тодорхойлсон дүнг 1-р тахирмагт үзүүлэв. 


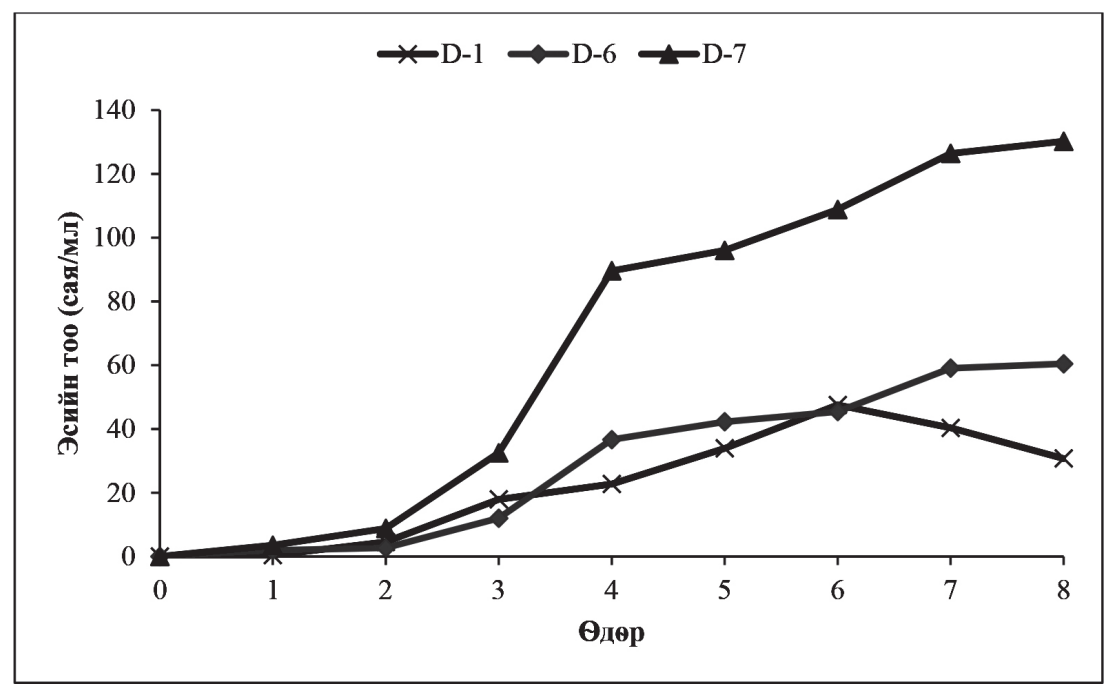

3ураг 1. Dunaliella Д-1, Д-6, Д-7 өсгөврийн өсөлтийн эрчим

Зураг 1-ээс харахад Dunaliella Д-1 өсгөвөр нь өсгөвөрлөлтийн 3 дахь өдрөөс эрчимтэй урган, 6 дахь өдөр өсөлтийн оргил цэг (45.4 сая/мл)-тээ хүрч байхад, Dunaliella Д-6, Д-7 өсгөврүҮд өсгөвөрлөлтийн 3 дахь өдрөөс эрчимтэй ургаж 7 дахь өдөрт өсөлтийнхөө дасан зохицох шатанд хүрч байна. Dunaliella Д-1, Д-6 өсгөврүүдийн өсөлтийн эрчим ойролцоо ба эсийн тоогоор авч үзэхэд Д-7 өсгөвөр нь Д-1 ба Д-6 өсгөврөөс $2-2.9$ дахин их эс хуримтлуулж байна.

Судлаач Хэйдари болон түүний багийнхан D.salina замгийн өсөлтийн эрчимд үзүүлэх тэжээлт орчны эрдсийн найрлага, гэрэлтүүлэлтийн нөлөөг туршсан ба уг туршилтанд эсийн тоо 55 сая/млээс 160 сая/мл хүртэл хэлбэлзэж байв. УГ судалгааны дүнгээс дунальелла замгийн өсөлтийн эрчимд өсгөвөрлөх орчин чухал нөлөөтэй төдийгүй тохиромжтой нөхцлийг бүрдүүлсэнээр өсөлтийн эрчимыг нэмэгдүүлэх боломжтой болохыг харуулжээ [12]. Иймд цаашдын судалгаагаар Dunaliella Д-1, Д-6, Д-7 өсгөврийн өсөлтийн эрчимд үзүүлэх орчны нөлөөг судлах шаардлага гарч байна.

\section{2. Эсийн морфологи}

Dunaliella Д-1, Д-6, Д-7 өсгөврийн эсийн хэлбэр зүйн зарим үзүүлэлтийг микроскопын тусламжтай ажигласан дүнг Хүснэгт 1.энд харуулав. Хүснэгтээс үзэхэд Д-1 өсгөврийн эс зуйвандуу хэлбэртэй, 8.1х5.0 мкм хэмжээтэй, ногоон өнгөтэй, хөдөлгөөнтэй, урд хэсэгтээ ганц бөөмтэй, хойд хэсгээрээ аяга хэлбэрийн хроматофортой байна.

ХУснэгт 1. Dunaliella Д-1, Д-6, Д-7 өсгөврийн эсийн зарим ҮзҮҮлэлт

\begin{tabular}{clccc}
\hline \multirow{2}{*}{ Өсгөвөр } & \multirow{2}{*}{ Эсийн хэлбэр } & \multirow{2}{*}{ Хроматофорын хэлбэр } & \multicolumn{2}{c}{ Эсийн хэмжээ (мкм) } \\
\cline { 4 - 5 } & & Аяга & 8.1 & Урген \\
\hline Д-1 & Зуйвандуу & Аяга & 10.2 & 6.0 \\
Д-6 & Зуйван & Аяга & 10.4 & 6.4 \\
Д-7 & Зуйван & Ауа & 6.2 \\
\hline
\end{tabular}


Д-6 өсгөврийн эсийн хэлбэр нь зуйван, 10.2х6.4 мкм хэмжээтэй, ногоон өнгөтэй, урд хэсэгтээ хос шилбүуртэй, түүнийхээ тусламжтай хөдөлдөг. Эсийн дотор урд хэсэгтээ ганц бөөмтэй, хойд хэсгээрээ аяга хэлбэрийн хроматофортой байна. Д-7 өсгөвөр нь морфологийн хувьд Д-6 өсгөвөртэй ойролцоо бөгөөд эсийн хэлбэр нь зуйван, $10.4 \times 6.2$ мкм хэмжээтэй, эсийн урд хэсэгтээ ганц бөөмтэй, хойд хэсгээрээ аяга хэлбэрийн хроматофортой, хос шилбүүрийхээ тусламжтай хөдөлдөг.
Dunaliella Д-6, Д-7 өсгөврийн эс идэвхтэй хөдөлгөөнтэй бол Д-1 өсгөврийн эс харьцангуй хөдөлгөөн бага ялангуяа бие гүйцсэн эсвэл хуваагдалд орохоос өмнө хөдөлгөөнгүй болдог онцлогтой.

\section{3. Уургийн агууламж}

Dunaliella Д-6, Д-1, Д-7 өсгөврийг сонгосон орчинд өсгөвөрлөж өсөлтийн эрчимтэй үед биомассыг салган авч, лиофилизацын аргаар хатаан хуурай биомасс дахь уургийн агууламжийг тодорхойлж Зураг 1-д үзүүлэв.

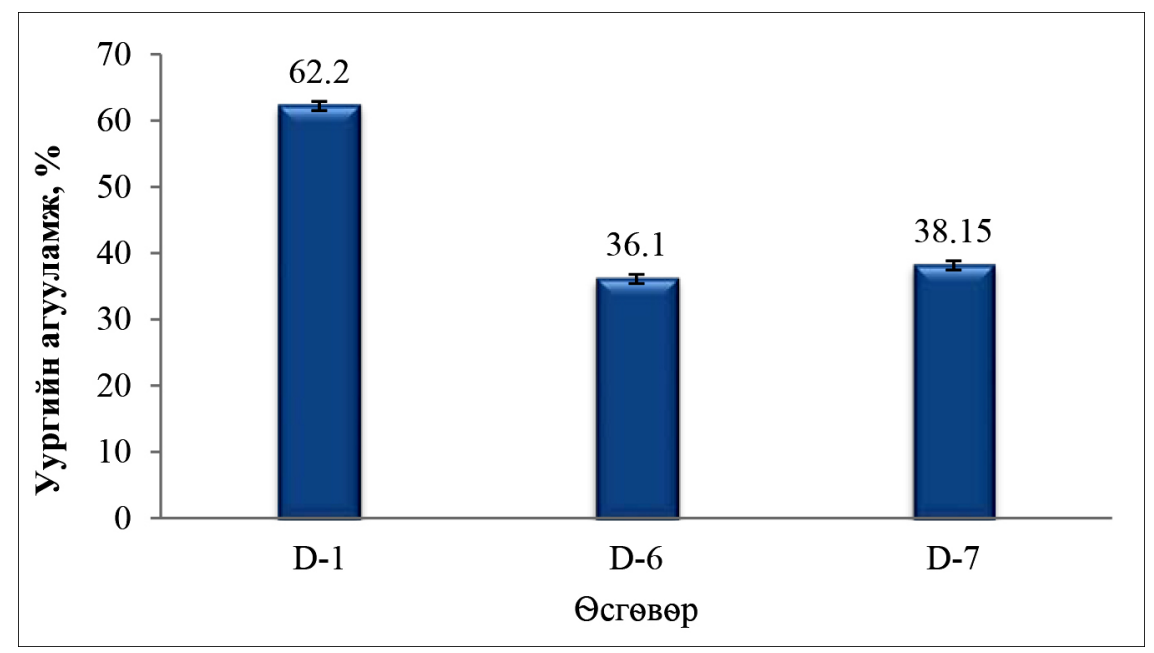

Зураг 2. Уургийн агууламж

Зураг 2-ээс харахад Dunaliella Д-1 нь $62.2 \%$, Dunaliella Д-6, Д-7 өсгөвөр нь $36.1 \%, 38.15 \%$ уургийн агууламжтай байна. Гадны судлаачдын судалгааны дүнгээс үзэхэд дунальелла замаг $22-60 \%$ уургийн агууламжтай $[8,13,14,15]$ энэ нь манай Dunaliella Д-6, Д-7 өсгөврүүдийн уургийн агууламжтай ойролцоо байна. Dunaliella Д-1 өсгөврийн уургийн агууламж харьцангуй өндөр байгаа тул цаашид уургаар баялаг бүтээгдэхүүн гарган авах туршилтанд ашиглах боломжтой юм.

\section{ДҮГНЭЛТ}

Микробын нийлэгжлийн лабораторийн бичил биетний сан дахь бичил замгийн Dunaliella Д-1, Д-6, Д-7 өсгөврийн өсөлтийн эрчимийг тодорхойлоход Dunaliella Д-7 өсгөвөр бусад өсгөврүүдээсээ 2 - 2.9 дахин их эс хуримтлуулж, хуурай биомасс дахь уургийн агууламжаар Д-1 өсгөвөр хамгийн их буюу 62.2\%-ийн уураг нийлэгжүүлж гадаадын судлаачдын дүнтэй ойролцоо тул цаашдын судалгаанд уургаар баялаг бүтээгдэхүүн гарган авах боломжтой болохыг тогтоов. 
Аиигласан бүтээлийн жагсаалт

1. Priyadarshani and B. Rath, "Commercial and industrial applications of micro algae -A review," J. Algal Biomass Util., vol. 3, no. 4, pp. 89-100, 2012.

2. T. M. Mata, A. A. Martins, and N. S. Caetano, "Microalgae for biodiesel production and other applications: A review," Renew. Sustain. Energy Rev., vol. 14, no. 1, pp. 217-232, Jan. 2010.

3. R. J. Radmer and B. C. Parker, "Commercial applications of algae: opportunities and constraints," J. Appl. Phycol., vol. 6, no. 2, pp. 93-98, Apr. 1994.

4. A. C. Guedes, H. M. Amaro, and F. X. Malcata, "Microalgae as sources of carotenoids," Mar. Drugs, vol. 9, no. 4, pp. 625-44, Jan. 2011.

5. K. Preetha, L. John, C. S. Subin, and K. K. Vijayan, "Phenotypic and genetic characterization of Dunaliella (Chlorophyta) from Indian salinas and their diversity," Aquat. Biosyst., vol. 8, no. 1, p. 27, 2012.

6. A. Sciandra, J. Gostan, Y. Collos, C. Descolas-Gros, C. Le Boulanger, V. MartinJézéquel, M. Denis, D. Lefêvre, G. Copin-Montégut, and B. Avril, "Growth-compensating Phenomena in Continuous Cultures of Dunaliella tertiolecta Limited Simultaneously by Light and Nitrate," Limnol. Oceanogr., vol. 42, no. 6, pp. 1325-1339, 1997.

7. A. Oren, "A hundred years of Dunaliella research: 1905-2005.," Saline Systems, vol. 1, no. 2, pp. 1-14, 2005.

8. A. Vanita, "Cultivation of Dunaliella bardawil rich in carotenoids and studies on nutritional and biological activities, "Univeristy of Mysore, 2007.

9. K. N. Chidambara Murthy, "Production of $\beta$-carotene from cultured Dunaliella sp. and evaluation of biological activities, " Central Food Technological Research Institute, 2005.

10. Н. Т. Буянххишг Н, “Давстай нуурын бичил замгийн судалгаа," Биологийн хүрээлэнгийн эрдэм шиннжилгээний бүтээл, по. 27, рр. 147-149, 2007.

11. Б. О. Бадгаа Д, Ургамлын биохимийн шинжилгээний арга. .

12. R. Heidari, H. Riahi, and S. Saadatmand, "Effect of salt and irradiance stress on photosynthetic pigments and proteins in Dunaliella salina teodoresco," J. Sci. I. R. Iran, vol. 11, no. 2, pp. 73-77, 2000.

13. N. Gibbs and C. M. Duffus, "Natural protoplast Dunaliella as a source of protein," Appl Env. Microbiol, vol. 31, no. 4, pp. 602-604, 1976.

14. G. Gonzalez-Benito, V. Barrocal, S. Bolado, M. Coca, and M. T. Garcia-Cubero, "Valorisation of by-products from food industry, for the production of single cell protein (SCP) using microalgae," N. Biotechnol., vol. 25, p. 262, 2009.

15. M. A. Borowitzka and L. J. Borowitzka, Microalgal biotechnology. London: Cambridge University Press, 1988. 


\title{
PHYSIOLOGICAL AND BIOCHEMICAL STUDIES ON DUNALIELLA MICROALGAE
}

\author{
Odgerel Bumandalai, Tserendulam Dugarsuren \\ Microbial Synthesis Laboratory, Institute of General and Experimental Biology, MAS, Ulaanbaatar, Mongolia \\ E-mail:odgerel@biology.mas.ac.mn,odgoo22@gmail.com
}

The genus Dunaliella is widely studied microalgae for its tolerance to extreme conditions, physiological aspects and many biotechnological applications, such as beta-carotene, protein, lipids and many other bioactive compounds. Physiological and biochemical studies are essential to fully explore the properties and possibilities of new isolates of Dunaliella.

The aim of this study was to describe cellular morphology, growth rate and protein content of three Dunaliella strains, isolated from salty lakes in Mongolia. The cellular morphology, growth rates, protein contents were studied using microscopic analyses, Neubauer's chamber, and micro kjeldahl method.

Results showed that growths of all three Dunaliella cultures were progressed through lag phase at $3^{\text {rd }}$ day. The growth of Dunaliella D-1 reached its peak on day 6, while Dunaliella D-6 and D-7 reached their stationary phase on day 7. Furthermore, the protein contents of dry biomass in Dunaliella D-1, D-6 and D-7 cultures were $62.2 \%, 36.1 \%$ and $38.15 \%$, respectively. The highest protein content was found in Dunaliella D-1 culture, hence this culture could be used as protein rich supplement in further study.

Key words: Dunaliella, microalgae, cell morphology. growth rate, protein. 